\title{
DOES SOCIAL PROGRESS EXPLAIN THE DIVIDEND PAYOUT DECISION?*
}

\author{
Hanaan Yaseen ${ }^{a}$
}

\begin{abstract}
This paper investigates whether national social progress influences dividend payout policy of companies around the world. Using a large database of 12,312 companies from 70 countries, for 7 years (2008-2014), I provide strong evidence that social progress is significant in relation to important corporate decisions on paying dividends. Dividend payout policy is explained by the social progress of the country in which the company is active. Access to higher education, satisfaction of basic human needs, overall wellbeing and opportunities positively influence the dividend payout ratio and the propensity to pay dividends. Moreover, the Social Progress Index may be more significant than GDP per capita in relation to dividend policy. Hence, the new measure of quantifying the population's standard of living, from the social perspective and not from the economic one, is more relevant in the decision-making process on dividend payout.
\end{abstract}

Keywords: Dividends, dividend policy, social progress, GDP per capita, country performance

JEL Classification: G35, G40, D90

\section{Introduction}

Social science and quality of life issues have raised a lot of interest in the last decades when trying to analyse corporate financial decisions from a sociological point of view. However, little research has been done to assess whether social progress affects economic or financial decisions. The social status of a country may motivate the country's citizens to act in one way or another. The degree to which the population has access to basic human needs, advanced education and more opportunities makes people develop a certain way of thinking and, at the same time, enables them to establish a specific set of actions in their day-to-day

* The author wishes to thank Victor Dragota for the useful ideas provided during the research. Also, special thanks go to participants of the XVII International Finance and Banking Conference, FIBA 2019, in Bucharest, Romania, on 28-29 March 2019 for their useful feedback and comments.

a Bucharest University of Economic Studies, Doctoral School of Finance and Center of Financial and Monetary Research (CEFIMO), Bucharest, Romania

Email: hanaan.yaseen@fin.ase.ro 
life. Hence, the Social Progress Index measures things that really matter to people. These important things which motivate the population to have specific feelings, emotions and needs also create premises based on which the people establish their plans for the future.

In addition to this, quality of life is not yet considered an explanatory variable for higher or lower dividends. Yaseen (2019) started to use the GDP per capita, as a proxy for standard of living, in relation to dividend payout policy. However, it could not cover the population's basic needs and other quality things that a country's citizens would appreciate. Therefore, the main scope of the paper is to find whether the Social Progress Index is more relevant than GDP per capita when we try to explain the dividend payout policy.

A higher quality of life may be linked with the desire to maintain that high level of overall wellbeing. Therefore, shareholders may decide to continue to remunerate all the investors or give them higher DPR because of the high need for access to opportunities.

By linking social progress to dividend policy, I provide evidence that higher dividends and higher propensity to distribute dividends are associated with higher national social progress. Also, access to education, more opportunities and the foundations of wellbeing determine higher payouts and increased likelihood that a company is a dividend payer. The results are consistent for both developed and developing countries.

I used a large database of 12,312 companies from 70 countries and I performed Panel Estimated Generalized Least Squares and Panel Logit models in order to investigate whether there is a significant association between the Social Progress Index (SPI) and dividend policy. The database includes all the companies' financial statements for a period of 7 years, from 2008 to 2014 .

To my knowledge, national social progress has not been analysed in relation to dividend policy. Therefore, the main interest of this article is to find a new argument for the question: "Why do companies distribute higher or lower DPR?"

The paper is organized as follows. Chapter 2 presents the importance of social progress and the potential link with corporate dividend policy. The main hypotheses of the study are also formulated in this section. Chapter 3 gives information about the data and the methodology used. Then, in Chapters 4 and 5, I show the empirical results of the study and robustness checks, respectively. Chapter 6 highlights the main conclusions and provides some ideas for further research.

\section{Social Progress, Dividend Policy and Hypotheses Tested}

Most humans create their future based on their desires and their perfect picture of their life. It is a tendency for people to work to create a better future or a better life for tomorrow. All of the goals that we set, all the actions that we do every day in order to achieve a specific 
goal are built based on a certain set of values and beliefs. These values are the result of all our experiences, emotional or other life experiences.

For example, if people have access to nutrition and good medical care, they may be less afraid to do riskier things in life. On the other hand, people may take more and quicker decisions if they know that their rights are protected and if they live in a country where their general wellbeing is on the agenda of the government or policy makers. Moreover, access to information and knowledge may also influence us in taking better-founded and clearer decisions in life. Also, the overall level of personal safety in a country may lead us to create a specific mindset and set of behavioural actions. All of these social aspects have never been analysed in relation to corporate decisions.

Dividend policy is one of the most important decisions within companies. The main theory that represents the basis of the irrelevance theory of dividend policy is the one stated by Miller and Modigliani (1961). Then, numerous researchers try to explain why companies distribute dividends and why they have a specific size. Some of the studies explain dividend policy through its signalling effect for higher earnings in the future (Bhattacharya, 1979; Miller and Rock, 1985). On the other hand, dividends can serve as a tool to minimize agency issues between shareholders and managers (Easterbrook, 1984; Jensen, 1986; Brockman and Unlu, 2009; Baker et al., 2011). Some other studies concluded that the signalling effect, agency issue minimization and even taxation are not relevant in relation to dividend payout policy (Brav et al., 2005; De Angelo and Skinner, 1996; Benartzi et al., 1997).

Social factors start to gain value when we look at the corporate decision on distributing dividends. Social factors provide structural elements of the country, which ultimately define the overall wellbeing of the population. These elements provide the way people organize themselves in life. How government and policy makers within a country prioritize each element on their annual agenda affects people's way of thinking and influences significantly how people develop their actions in life (Hahn and Inborn, 2009).

The main purpose of the Social Progress Index (SPI) is to move beyond the GDP. The GDP may capture the level of inequity that exists in a society from the social perspective (England, 1998). In the past decade, the GDP, as a country's development index, has been debated and challenged by other social indexes (Grasso and Canove, 2007). The GDP considers only economic aspects which can determine the economic growth if we compare the evolution of the GDP from one period to another. It is an economic measure, which was developed in the 1930s, as a statistical tool for policy makers to help and track the recovery after the Great Depression. The SPI identifies the social and environmental elements of a country's performance. The Social Progress Index quantifies three main elements that establish a very comprehensive framework of basic human needs, foundations of wellbeing, and opportunity. 


\section{Figure 1: Indicators considered within the Social Progress Index}

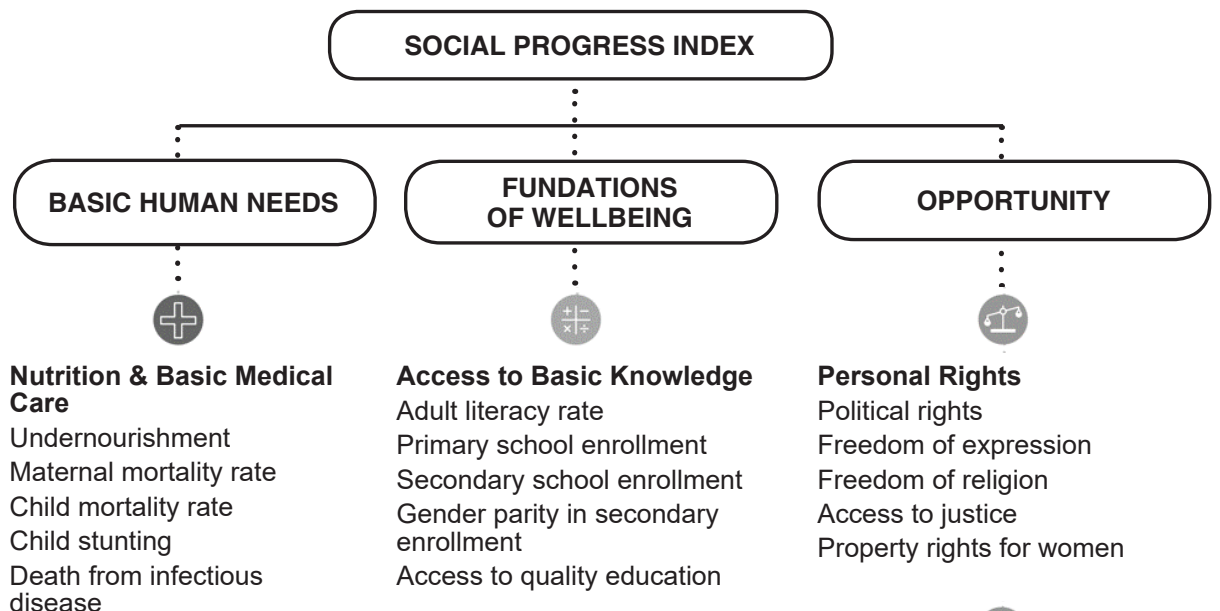

disease

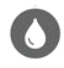

Water \& Sanitation

Access to at least basic drinking water

Access to piped water

Access to at least basic sanitation facilities

Rural open defecation

\section{Shelter}

Access to electricity

Quality of electricity supply

Household air pollution attributable deaths

Access to clean fuels and technology for cooking

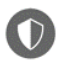

\section{Personal Safety}

Homicide rate

Political killing and torure

Perceived criminality

Traffic deaths
Health \& Wellness

Life expectancy at 60

Premature deaths from non-comminicable diseases

Access to essential health services

Access to quality healthcare

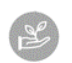

\section{Environmental Quality}

Outdoor air pollution attributable deaths

Greenhouse gas emissions

Biome protection

\section{Personal Freedom \& Choice \\ Vulnerable employment \\ Early marriage \\ Satisfed demand \\ for contraception \\ Corruption}

\section{Inclusiveness}

Acceptance of gays and lesbians

Discrimination and violence against minorities

Equality of political power by gender

Equality of political power by socioeconomic position Equality of political power by social group

\section{Access to Advanced Education}

Yars of tertiary schooling

Womens average years in school

Globaly ranked universities Percent of tertiary students enrolled in globally ranked universities 
According to the methodology ${ }^{1}$, the Basic Human Needs index quantifies how well a country provides the population with the essential needs. It measures the access to nutrition and basic medical care, whether they have access to basic utilities, safe drinking water and whether the country is safe and secure. Foundations of wellbeing highlight whether the population have access to education and information and conditions for living a healthy life. Opportunity tells us the degree to which the population have personal rights. Opportunity also means that the citizens have access to advanced education. As far as we can see, this indicator measures the social performance of a country and is independent of any economic factors. The overall Social Progress Index score is calculated is as the simple average of the three dimensions mentioned above. Each dimension is then the sum of four components of three equally weighted dimensions. In the end, each component is the weighted sum of a series of measures presented below, with the weights determined using principal component analysis.

All the indicators mentioned above are provided by the world's largest institutions ${ }^{2}$ such as United Nations and Transparency International and also collected by Social Progress Imperative from global surveys, such as Gallup's World Poll.

It can be seen that some richer countries in terms of GDP per capita are not able to turn this advantage into a higher Social Progress Index. There are many countries which are poorer from the GDP per capita perspective and which have higher quality of life in terms of Social Progress Index. (e.g., Costa Rica has a higher level of social progress than Italy, with barely a third of Italy's per capita GDP).

Figure 2 presents the association between GDP per capita and the Social Progress Index. It can be observed that for some countries, with similar levels of GDP per capita, the Social Progress Index is significantly different (e.g., Egypt $v s$. Macedonia, Russia $v s$. Estonia, Indonesia vs. Ukraine, Peru vs. China, Saudi Arabia vs. Netherlands, Mexico vs. Brazil, etc.).

1 https://www.socialprogress.org/index/methodology

2 More details regarding the different weights used resulting from the principal components analysis can be found at the following link within the Methodology Report: https://www.socialprogress.org/ assets/downloads/resources/2014/2014-Social-Progress-Index-Methodology.pdf . 
Figure 2: Association between Social Progress Index and GDP per capita

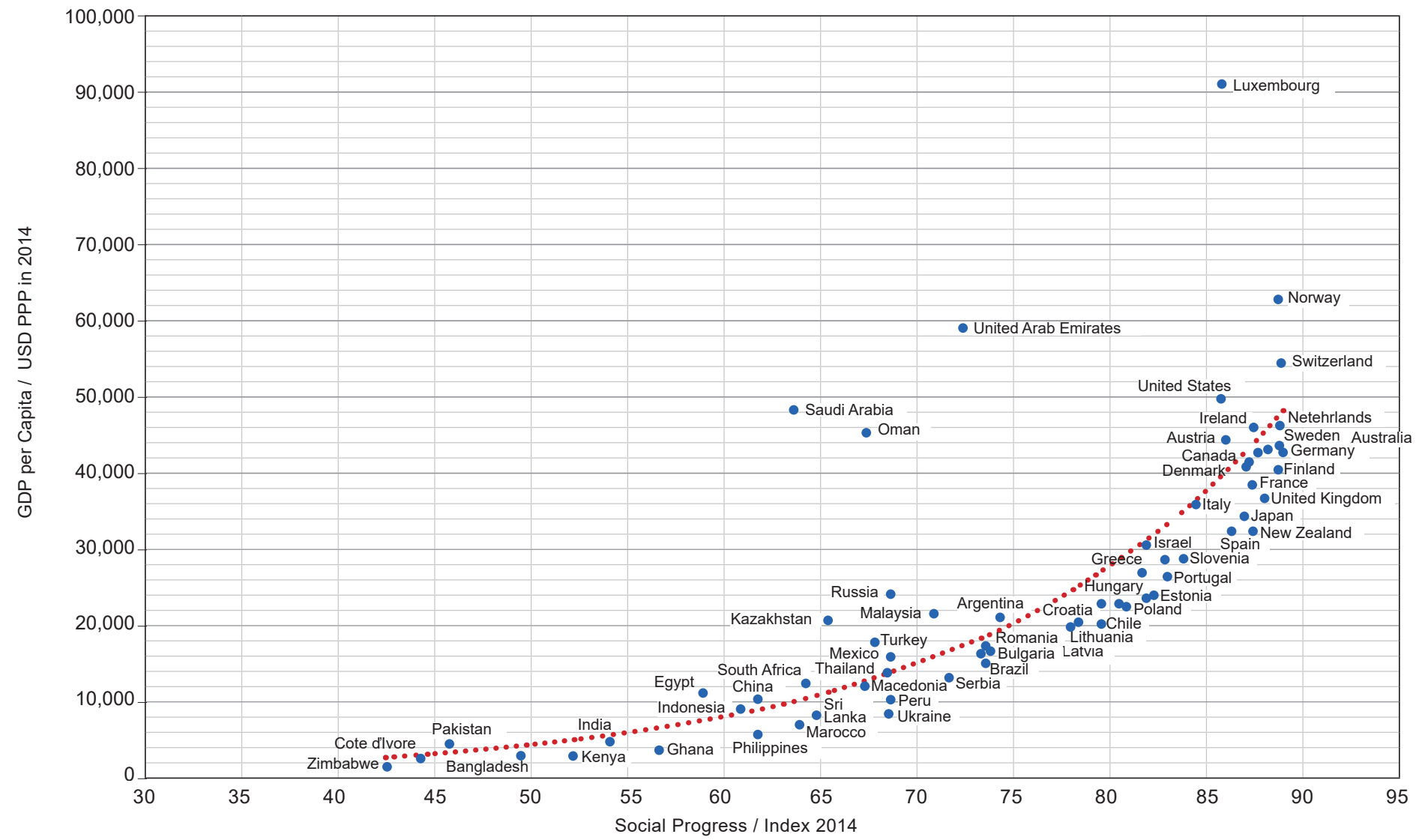

Source: own graph, data from Social Progress Imperative and World Bank 
Taking into consideration that social progress may be a better indicator than GDP per capita when we try to measure the country performance (Fleurbaey and Blanchet, 2013), I find it very interesting to investigate whether it affects the dividend magnitude and propensity around the world. Yaseen (2019) provides some evidence that standards of living, proxied by GDP per capita, and level of poverty, proxied by the Gini index, are representative in association with dividend policy. Therefore, a first hypothesis is set as follows:

Hypothesis 1: The Social Progress Index is more significant than GDP per capita when we try to explain the dividend payout ratio and the propensity to distribute dividends.

Therefore, I shall provide evidence that for studies where GDP per capita explains a phenomenon, maybe social progress could also be a good determinant, or even a better one, for explaining the same phenomenon. The advantage would then be that specific actions could be taken by policy makers to have a direct impact on overall population wellbeing.

Moreover, I consider that a lower Social Progress Index may lead to lower dividend payout ratios because people are used to live with fewer resources, less food, less education, etc. Also, in countries with lower social progress, companies may use more internal resources in order to invest in new projects. At the same time, countries with higher Social Progress Index may have better access to finance for their projects from external resources. This may lead to higher dividend payout ratios and also higher propensity that companies will distribute dividends. Hence, a second hypothesis is as follows:

Hypothesis 2: The Social Progress Index influences positively the dividend payout ratio and the propensity to distribute dividends.

This hypothesis can have the same effect as the classic theories on dividend policy. For example, it can be associated with the "bird-in-the-hand" theory (Litner, 1962) and with the signalling theory. However, now we may have a new factor that may explain higher dividends or higher probability that a company distributes dividends. 


\section{Data and Empirical Specifications}

\subsection{Data}

Using a large sample of 12,312 companies from 70 countries $^{3}$ and for a period of 7 years (from 2008 to 2014), I perform an analysis to see if the social progress influences significantly the dividend size and the propensity to distribute dividends. The same database was used in Yaseen (forthcoming) ${ }^{4}$. Financial institutions were excluded from the database. Companies' financial data were obtained from the Thomson Reuters Worldscope database 5 . I kept in the analysis only companies which reported all the financial indicators, including dividends for the entire period analysed. Also, the final database consists of countries which have at least 10 companies with a full set of financial indicators. All companies with at least one abnormal value for a financial indicator were excluded (i.e., companies which reported negative value for assets, negative value for equity, etc). Data regarding legal origin were collected from Andrei Shleifer's database ${ }^{6}$. Almost the same database was used in Yaseen (2019), Yaseen and Dragota (2019), Dragota et al (2019), Yaseen et al. (forthcoming), Yaseen (2018).

To control the models with the firm-specific determinants, I used the most representative variables presented by Yaseen (2018): return on equity (RoE, defined as net profit per equity), company size (proxied by natural logarithm of total assets), volatility of shares for the last 5 years (beta value), lagged leverage (total liabilities to total equity), foreign holdings (percentage of foreign investors) and legal origins (as per La Porta et al., 2000). Please refer to Yaseen (2018) for more details regarding formulas and related studies.

The Social Progress Index (SPI) was collected from The Social Progress Imperative - a global non-profit organization ${ }^{7}$ that provides very insightful data on social health, for almost all the countries (146 countries) around the world. Appendix 4 shows a Social Progress Index map for all the countries.

3 These countries are: Argentina, Australia, Austria, Bahrain, Bangladesh, Belgium, Brazil, Bulgaria, Canada, Chile, China, Cote d'Ivoire, Croatia, Czech Republic, Denmark, Egypt, Estonia, Finland, France, Germany, Ghana, Greece, Hungary, India, Indonesia, Ireland, Israel, Italy, Japan, Kazakhstan, Kenya, Kuwait, Latvia, Lithuania, Luxembourg, Macedonia, Malaysia, Malta, Mauritius, Mexico, Morocco, Netherlands, New Zealand, Norway, Oman, Pakistan, Peru, Philippines, Poland, Portugal, Romania, Russia, Saudi Arabia, Serbia, Slovenia, South Africa, Spain, Sri Lanka, Sweden, Switzerland, Thailand, Turkey, Tunisia, Ukraine, United Arab Emirates, United Kingdom, United States, Venezuela, Zambia, Zimbabwe.

4 Yaseen, H. (forthcoming). Do the classical determinant factors still influence the dividend policy? Paper presented at FIBA Conference on 28-29 March 2019.

5 Access to the database was provided by Deloitte Management Consulting in Romania.

$6 \mathrm{http} / / /$ scholar.harvard.edu/shleifer/publications/economic-consequences-legal-origins

7 https://www.socialprogress.org/ 
The Social Progress Index was launched in 2014. Therefore, I took only the data for 2014 and they were considered stable for the entire period analysed. I considered that social progress does not change significantly from one year to another. I checked this assumption for the period 2014-2018. Greatest changes were registered in very small countries which are not part of my database. The same stability is also found in relation to cultural values. It is proved that cultural dimensions can be stable for hundreds of years (Guiso et al., 2006). There are a lot of studies which analyse stable cultural dimensions quantified only in one year, to explain the differences in the dividend policy around the world (Fidrmuc and Jacob, 2010; Shao et al., 2010; Bae et al., 2012; Yaseen and Dragota, 2019).

For representing the social progress as being one of the determinants of the dividend policy, I have chosen to test the Social Progress Index (overall index as presented by Social Progress Imperative) together with other four components that determine it. Three of them are the main pillars of the SPI: basic human needs, foundations of wellbeing and opportunity. The fourth one is a component of the third pillar. It is 'access to advanced education'. It has been proven that access to advanced education leads to better mental and physical health and can also create premises for a better standard of living. Therefore, I find it very interesting to see if this indicator is significant in determining higher or lower dividends.

In order to see if the SPI could be a more relevant indicator which could be used to explain a specific dividend payout policy, I tested the GDP per capita first (as in Yaseen, 2019, but using a larger database now). The data for the GDP per capita were collected from the World Bank database 8 . I used a proxy for the quality of life for the population which lives in a specific country (Dipietro and Anoruo, 2006; Grasso and Canova, 2007). Now, in this study, we can say that the SPI is also a good proxy for citizens' quality of life which can be used to highlight differences in the standard of living, but from a social perspective and not an economic one.

In Appendix 1, I present the descriptive statistics of all the variables used, and the correlation matrix between variables is shown in Appendix 2. To avoid multicollinearity, I included in the same model only data which are not correlated (correlation index lower than $30 \%$ ). All the financial variables were $2 \%$ winsorized and I kept only companies that have a dividend payout ratio higher than 0 .

\subsection{Empirical specifications}

To examine the impact of social progress on the dividend payout policy, I estimate the following baseline Panel Estimated Generalized Least Square model:

https://data.worldbank.org/indicator/SI.POV.GINI/ 


$$
D P R_{i t}=\mathrm{C}+\sum_{i} \gamma_{i} \text { Control variables }_{i t}+\sum_{i} \beta_{i} \text { Legal origin }_{i t}+\sum_{i} \alpha_{i} \text { Social Progress }_{i t}+\omega_{i t},
$$

where $i$ represents each company, $t$ is the year between 2008 and 2014, firm characteristics (control variables) are those generally used in the literature ${ }^{9}, C$ is the constant term of the model, $\beta_{k}, \gamma_{j}$ and $\alpha_{i}$ are the estimated coefficients and $\omega_{i t}$ is the random effect equal to $\varepsilon_{i}+v_{i t}$. A country random effect was applied to all the regressions. Please note that it for the legal origin and social progress indexes is constant across all companies active in a specific country and across all years analysed.

For testing the impact of the same variables on the probability to distribute dividends, I also performed a Panel Logit regression as follows:

$$
\text { PRP }_{i t}=\mathrm{C}+\sum_{j} \gamma_{j} \text { Control variables }_{j t}+\sum_{i} \beta_{i}{\text { Legal } \text { Origin }_{i t}}+\sum_{i} \alpha_{i} \text { Social Progress }_{i t}+\varepsilon_{i t},(2)
$$

where $i$ represents each company, $t$ is the year between 2008 and 2014, $C$ is the constant term of the model, $\beta_{k}, \gamma_{j}$ and $\alpha_{i}$ are the estimated coefficients and $\varepsilon_{i t}$ is the error term of the logistic regression.

Similar models were also used in Yaseen ${ }^{10}$ (forthcoming). The dependent variable used in the PEGLS model in this case is the Dividend Payout Ratio (DPR), defined as dividends over net income, based on the following formula:

$$
D P R_{t}=\frac{\text { Dividends }_{t}}{\text { Netincome }_{t}} .
$$

For the Logit model, I used Propensity (PRP) as the dependent variable. It is defined as a binary response variable, equal to 1 if the company distributed dividends, 0 otherwise. The findings are robust to alternative measures of dividend payout, including dividend to total assets, dividend yield and dividend per net equity. These variables are considered relevant for representing the dividend policy (Aivazian et al., 2003; Fidrmuc and Jacob, 2010; Chen et al., 2017; Yaseen, forthcoming). The main variables of interest in this study are the Social Progress Indexes: Overall Social Progress Index, Basic Human Needs, Foundations of Wellbeing, Opportunity and Access to Advanced Education. Therefore, I focus only on the models which address this issue better and which are the most representative in highlighting the association and the influence of the social factors on the dividend payout decision. All the determination ratios of the models increase when an additional social variable is included on top of the classic dividend payout determinants.

9 Please refer to Appendix 6 for a detailed description of the control variables used.

10 Yaseen, H. (forthcoming). Do the classical determinant factors still influence the dividend policy? Paper presented at FIBA Conference on 28-29 March 2019. 


\section{Empirical Results and Discussion}

Table 1 presents the results of the EGLS model for all the countries. All the control variables are significant and with the same association as presented in the literature (Aivazian et al., 2003; Denis and Osobov, 2008; Fidrmuc and Jacob, 2010).

Importantly, the Social Progress Indexes are associated with higher dividend payout ratios (please see the chart in Appendix 5 showing the relationship between SPI and DPR). When looking at the overall Social Progress Index (SPI) we can say that it explains better than GDP per capita the share of profits distributed as dividends. The determination ratio for model 7 (53.72\%) is higher than it is for model 2 (41.09\%). Moreover, we can highlight that, when using the SPI in trying to explain the DPR (model 7), we reach a higher adjusted $R^{2}$ than in the classic model (model 1). Therefore, the way people live in their country influences the corporate decision to distribute higher dividends. If in a specific country, the social progress is high, the companies which are active in that specific country distribute higher dividends out of the net earnings.

This could be explained by the fact that those people are used to live at higher standards, and maybe, the dividends represent a stable source of revenues for them and they do not want to alter it. On the other hand, companies which operate in a low social progress country may decide to distribute lower dividends because they can wait longer to have higher income in the future. They will reinvest the money in order to have a chance for higher revenues sometimes in the future. Also, social progress may also be associated with higher quality of health services, which may require higher costs for accessing them. For example, companies which are active in Tier 1 countries $^{11}$, with the highest SPI (e.g., Canada, Norway) distribute higher dividends than companies activate in Tier 2 countries (e.g., Australia, France, USA, Czech Republic), Tier 3 (e.g., Russia, Argentina, Romania), etc.

At the same time, all the determinants of social progress are relevant and positively associated with the dividend payout ratio. However, if we take them one by one, we can say that some of them are more significant than others. For example, access to higher education, access to basic human needs and opportunities are not more relevant than the GDP in relation to the dividend payout decision. On the other hand, foundations of wellbeing, determined by access to information, health, environmental quality and access to basic knowledge, seem to be more representative than GDP per capita in relation to the DPR. From the economic perspective, all of the elements that are considered part of wellbeing also require higher expenses in order to maintain the same standard. Therefore, dividends can be seen as an additional revenue stream for the population which is higher on the foundations of wellbeing.

11 The full list of countries used in the analysis and the SPI for each country are presented in Appendix 3. Also, the world map with the 6 tiers of SPI is presented in Appendix 4. 
Table 1 shows the models that best represent the influence of social progress on dividend payout ratio. All models are Panel EGLS regression analyses. These models are selected to be the most representative taking into consideration the informational criteria indicators: AIC, BIC and log likelihood. Model 1 is the baseline taken from Yaseen (forthcoming). For analysing the impact of social progress on DPR, I excluded Scandinavian civil law (sc_civil law) because it is correlated with higher Social Progress Indexes. Please refer to the correlation matrix in Appendix 2.

Table 1: Impact of social progress on the dividend policy - Panel A: All countries

\begin{tabular}{|c|c|c|c|c|c|c|c|}
\hline \multirow{3}{*}{$\begin{array}{l}\text { Dependent } \\
\text { variable }\end{array}$} & \multicolumn{7}{|c|}{ DPR } \\
\hline & Model 1 & Model 2 & Model 3 & Model 4 & Model 5 & Model 6 & Model 7 \\
\hline & \multicolumn{7}{|c|}{ Panel A - all 70 countries } \\
\hline C & 43.7510 & -3.1515 & 28.5507 & 11.4997 & 8.8004 & 30.0251 & 20.0124 \\
\hline ROE & 0.1860 & 0.1989 & 0.1810 & 0.2099 & 0.2052 & 0.1752 & 0.1962 \\
\hline LN_TOTAL_ASSETS & 0.4180 & 0.5757 & 0.6253 & 0.6288 & 0.7269 & 0.4964 & 0.5394 \\
\hline BETA_VALUE & -12.5060 & -12.9795 & -13.4573 & -13.6193 & -12.5485 & -12.2456 & -12.9256 \\
\hline FOREIGN_HOLDINGS & 0.0160 & 0.01610 & 0.0132 & $0.0167^{* *}$ & $0.0129 * * *$ & $0.0190 *$ & $0.0089^{* * *}$ \\
\hline$L E V(-1)$ & -1.1830 & -1.2551 & -1.2745 & -1.2909 & -1.3464 & -1.2847 & -1.2878 \\
\hline fr_civil law & -8.4240 & -5.2976 & -4.6143 & -5.6560 & -5.3952 & -5.3413 & -5.1910 \\
\hline gr_civil law & -14.5160 & -10.6394 & -11.1259 & -12.1912 & -11.0123 & -11.3167 & -11.2077 \\
\hline sc_civil law & -7.4980 & - & - & - & - & - & - \\
\hline GDP per capita & - & 4.2914 & - & - & - & - & - \\
\hline Access to education & - & - & 0.2270 & - & - & - & - \\
\hline Basic human needs & - & - & - & 0.3267 & - & - & - \\
\hline Wellbeing & - & - & - & - & 0.3542 & - & - \\
\hline Opportunity & - & - & - & - & - & 0.1614 & - \\
\hline Social Progress Index & - & - & - & - & - & - & 0.2614 \\
\hline Cross-country weights & Yes & Yes & Yes & Yes & Yes & Yes & Yes \\
\hline $\begin{array}{l}\text { Country random } \\
\text { effects }\end{array}$ & Yes & Yes & Yes & Yes & Yes & Yes & Yes \\
\hline Adjusted $R^{2}(\%)$ & 49.93 & 41.09 & 38.15 & 42.35 & 59.31 & 47.02 & 53.72 \\
\hline
\end{tabular}

Note: All coefficients are significant from the statistical point of view, at the $0 \%$ significance level, except

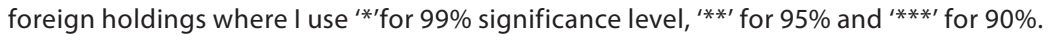

Source: Own calculation using Eviews 10.0 
Table 2 shows the models that best represent the impact of social progress on the propensity of dividends. All models are based on Panel Logit methodology. These models are selected to be the most representative taking into consideration the informational criteria indicators: AIC, BIC and log likelihood. Model 1 is the baseline taken from Yaseen (forthcoming). For analysing the impact of social progress on DPR, I excluded Scandinavian civil law (sc_civil law) because it is correlated with higher Social Progress Indexes. Please refer to the correlation matrix in Appendix 2.

Table 2: Impact of social progress on propensity to distribute dividends - Panel A: All countries

\begin{tabular}{|c|c|c|c|c|c|c|c|}
\hline \multirow{3}{*}{$\begin{array}{l}\text { Dependent } \\
\text { variable }\end{array}$} & \multicolumn{7}{|c|}{ Propensity } \\
\hline & Model 1 & Model 2 & Model 3 & Model 4 & Model 5 & Model 6 & \multirow[t]{2}{*}{ Model 7} \\
\hline & \multicolumn{6}{|c|}{ Panel A - all 70 countries } & \\
\hline$C$ & -1.9921 & -6.2407 & -3.3464 & -4.0782 & -5.2092 & -3.3388 & -3.8012 \\
\hline ROE & 0.0582 & 0.0593 & 0.0591 & 0.0590 & 0.0601 & 0.0583 & 0.0586 \\
\hline LN_TOTAL_ASSETS & 0.2407 & 0.2556 & 0.2490 & 0.2537 & 0.2589 & 0.2459 & 0.2469 \\
\hline BETA_VALUE & -0.5843 & -0.5724 & -0.6731 & -0.5827 & -0.5866 & -0.5615 & -0.5809 \\
\hline FOREIGN_HOLDINGS & -0.0037 & -0.0058 & -0.0058 & -0.0049 & -0.00623 & -0.0059 & -0.0053 \\
\hline$L E V(-1)$ & -0.1617 & -0.1700 & -0.1711 & -0.1703 & -0.17544 & -0.1684 & -0.1702 \\
\hline fr_civil law & -0.8624 & -0.5808 & -0.4452 & -0.6512 & -0.52546 & -0.5572 & -0.5849 \\
\hline gr_civil law & -0.9225 & -0.4764 & -0.4529 & -0.6916 & -0.4144 & -0.4837 & -0.5624 \\
\hline sc_civil law & -0.5375 & - & - & - & - & - & - \\
\hline GDP per capita & - & 0.3840 & - & - & - & - & - \\
\hline Access to education & - & - & 0.0235 & - & - & - & - \\
\hline Basic human needs & - & - & - & 0.0203 & - & - & - \\
\hline Wellbeing & - & - & - & - & 0.0344 & - & - \\
\hline Opportunity & - & - & - & - & - & 0.0163 & - \\
\hline $\begin{array}{l}\text { Social Progress } \\
\text { Index }\end{array}$ & - & - & - & - & - & - & 0.0201 \\
\hline $\begin{array}{l}\text { Cross-country } \\
\text { weights }\end{array}$ & Yes & Yes & Yes & Yes & Yes & Yes & Yes \\
\hline $\begin{array}{l}\text { Country random } \\
\text { effects }\end{array}$ & Yes & Yes & Yes & Yes & Yes & Yes & Yes \\
\hline Adjusted $R^{2}(\%)$ & 13.67 & 14.25 & 14.59 & 14.11 & 15.06 & 14.10 & 16.23 \\
\hline
\end{tabular}

Note: All coefficients are significant from the statistical point of view, at the $0 \%$ significance level. Source: Own calculation using Eviews 10.0 
The results strongly support the hypotheses formulated in the previous section. The level of access to education, the degree of satisfaction of basic human needs, the level of wellbeing and the opportunity level positively influence the dividend payout ratio. Opportunity means that people benefit from better political rights, more freedom of expression, lower corruption, and better access to higher and longer education. All of these influence positively the level of dividends paid by companies active in countries characterized by higher levels of opportunities.

In addition to this, the models reveal a positive influence of the Social Progress Indexes on the probability that a company is a dividend payer. If the country is characterized by better access to advanced education, higher wellbeing of the population and the population has all the basic human needs satisfied, then companies that operate in these countries have a higher dividend propensity. This aspect is also very important since it has been proven in the literature that an increasing number of companies have started to be non-dividend payers in the recent years (Fama and French, 2001; Denis and Osobov, 2008).

Therefore, I provide significant and strong evidence that quality of life from the social perspective may lead to higher DPR and higher propensity to distribute dividends, while considering the proxy variables on top of the classical factors from the existing literature (firm-specific indicators).

\section{Robustness Checks}

For robustness checks, I divided the sample into two: companies that are active in developed countries and companies that operate in emerging countries. The split was made based on World Bank classification between developed and emerging economies. Panel B represents the developed countries and Panel $\mathrm{C}$ the emerging ones.

$\mathrm{I}$ also employed a number of sub-period regressions and year-by-year regressions in order to test the data consistency. Also, I ran the models for 3-4 countries only and the results remained the same. The sign of the explicative constant was always constant. I also performed quartile regressions for the quartile level of $0.1,0.3,0.5,0.7$ and 0.9 . All the models reveal the same association. Social progress influences positively the dividend payout ratio and the probability to distribute dividends. Also, another measure for dividend policy was tested: dividend per sales. It is also a structural ratio and the association is the same as for the DPR. Please refer to Yaseen and Dragota (forthcoming) for the related studies regarding the alternative measures for the dividend payout ratio. 
Table 3: Impact of social progress on the dividend payout ratio - Split between developed (Panel B) and emerging (Panel C) countries

\begin{tabular}{|c|c|c|c|c|c|c|c|c|c|c|}
\hline \multirow{3}{*}{$\begin{array}{l}\text { Dependent } \\
\text { variable }\end{array}$} & \multicolumn{10}{|c|}{ DPR } \\
\hline & \multicolumn{5}{|c|}{ Panel B } & \multicolumn{5}{|c|}{ Panel C } \\
\hline & 221.8793 & $-1.884^{* *}$ & 20.6418 & -10.1538 & -33.1076 & 27.2446 & 48.1331 & 28.0366 & 22.1867 & 37.4624 \\
\hline ROE & 0.1110 & 0.0782 & 0.106899 & 0.1005 & 0.0844 & 0.3136 & 0.2914 & 0.3195 & 0.2921 & 0.2912 \\
\hline $\begin{array}{l}\text { LN_TOTAL } \\
\text { ASSETS }\end{array}$ & 0.9797 & 0.3700 & 0.8779 & 0.8754 & 0.7887 & - & - & - & - & - \\
\hline BETA_VALUE & -11.2700 & -12.0847 & -10.4151 & -10.8217 & -10.6423 & -14.0068 & -14.8465 & -13.9070 & -13.5275 & -13.9834 \\
\hline $\begin{array}{l}\text { FOREIGN_ } \\
\text { HOLDINGS }\end{array}$ & -0.1026 & -0.0974 & -0.1179 & -0.0804 & -0.0969 & 0.0432 & 0.0427 & 0.0350 & 0.0311 & 0.0329 \\
\hline $\operatorname{LEV}(-1)$ & -1.0150 & -0.7925 & -0.8470 & -0.6511 & -0.7034 & -1.7643 & -1.7340 & -1.6761 & -1.5472 & -1.7363 \\
\hline fr_civil law & -2.2856 & -5.8119 & $-0.655^{* *}$ & -3.2207 & -1.9620 & -8.0798 & -7.2432 & -8.6556 & -7.8427 & -7.8757 \\
\hline gr_civil law & -13.8009 & -4.3768 & -10.6166 & -7.6322 & -9.9155 & -13.8819 & -13.4356 & -15.8671 & -14.0760 & -14.0249 \\
\hline GDP per capita & 17.6068 & - & - & - & - & 2.1561 & - & - & - & - \\
\hline $\begin{array}{l}\text { Access } \\
\text { to education }\end{array}$ & - & 0.7617 & - & - & - & - & -0.0214 & - & - & - \\
\hline $\begin{array}{l}\text { Basic human } \\
\text { needs }\end{array}$ & - & - & 0.1635 & - & - & - & - & 0.2582 & - & - \\
\hline Wellbeing & - & - & - & - & - & - & - & - & 0.3551 & - \\
\hline Opportunity & - & - & - & 0.5832 & - & - & - & - & - & - \\
\hline $\begin{array}{l}\text { Social Progress } \\
\text { Index }\end{array}$ & - & - & - & - & 0.8076 & - & - & - & - & 0.1521 \\
\hline $\begin{array}{l}\text { Cross-country } \\
\text { weights }\end{array}$ & Yes & Yes & Yes & Yes & Yes & Yes & Yes & Yes & Yes & Yes \\
\hline $\begin{array}{l}\text { Country random } \\
\text { effects }\end{array}$ & No & No & No & No & No & No & No & No & No & No \\
\hline Adjusted $R^{2}$ (\%) & 38.62 & 35.61 & 34.69 & 25.06 & 23.58 & 57.29 & 75.03 & 72.68 & 68.14 & 64.70 \\
\hline
\end{tabular}

Source: Own calculation using Eviews 10.0

A similar split between developed and developing countries was made for checking the consistency of the models that explain the propensity of distributing dividends ${ }^{12}$. All social progress indicators remain consistent, relevant and with a significant influence on propensity of dividends, except the Basic Human Needs index for developing countries. Therefore, we have relevant evidence that social progress influences positively the dividend policy around the world.

12 All the other robustness checks are available upon request. 
In addition to this, I tested for potential endogeneity problems. A simple inverse causality between DPR, propensity (explicative variables) and Social Progress Indexes (dependent variable) show us that a country's performance from the social perspective is not influenced significantly by a higher level of DPR or by a higher probability that companies active in the country distribute dividends.

\section{Conclusions}

The results of the study show that country performance, measured using the Social Progress Index (SPI), significantly influences corporate dividend payout policy. In ad- dition to that, this empirical analysis provides evidence that the SPI may be a more significant determinant factor than GDP per capita when we want to find explanations for the dividend payout ratio and whether a company distributes dividends or not.

For example, if we take Egypt and Macedonia, which have similar levels of GDP per capita, we can say that the probability that a company is a dividend payer is higher in Macedonia, because of a higher Social Progress Index. In addition, companies that operate in Macedonia may distribute a higher share of their net earnings as cash dividends than companies that operate in Egypt. Another example is Peru vs. China. Since Peru is characterized by higher social progress than China, companies active in Peru may have higher dividend payout ratios and higher dividend propensity than companies active in China. The examples may continue with all the countries if we are interested in comparing companies around the world from the dividend policy perspective.

These findings are consistent with the general hypothesis that higher social progress requires higher income for the shareholders to maintain their standard of living, and therefore higher dividend payout ratios may apply. Also, these findings are in line with the "birdin-the-hand" theory of dividends saying that cash now is preferable over potential cash in future. This preference may be more common among population that is used to having a higher standard of living.

The conclusion indicates that national social progress may be a significant omitted variable in the literature when trying to explain different corporate decisions on distributing dividends. All the robustness checks prove that the Social Progress Index, Access to Advanced Education, Basic Human Needs, Foundations of Wellbeing and Opportunities within a country are all relevant when we try to explain a higher dividend payout ratio or a higher probability that a company will distribute dividends.

The study is useful for international investors looking to buy shares with higher dividends or shares in companies with higher likelihood to distribute dividends in the future. The study is also useful for policy makers who would like to entice higher dividends or dividend payments. 
Appendix 1: Descriptive statistics of all variables

\begin{tabular}{|c|c|c|c|c|c|c|c|c|c|c|c|}
\hline & & Mean & Median & $\begin{array}{l}\text { Maxi- } \\
\text { mum }\end{array}$ & $\begin{array}{l}\text { Mini- } \\
\text { mum }\end{array}$ & $\begin{array}{l}\text { Std. } \\
\text { dev. }\end{array}$ & $\begin{array}{c}\text { Skew- } \\
\text { ness }\end{array}$ & $\begin{array}{l}\text { Kurto- } \\
\text { sis }\end{array}$ & $\begin{array}{l}\text { Jarque- } \\
\text {-Bera }\end{array}$ & $\begin{array}{l}\text { Proba- } \\
\text { bility }\end{array}$ & Obs \\
\hline GDP_CAPITA & mUSD & $20,985.97$ & $14,367.60$ & $90,950.01$ & $2,906.83$ & $14,965.50$ & 0.83 & 2.92 & 4,269 & 0.00 & 78,736 \\
\hline$L A W \_F R$ & Dummy & 0.24 & 0.00 & 1.00 & 0.00 & 0.43 & 1.20 & 2.43 & 9,410 & 0.00 & 78,736 \\
\hline$L A W \_G R$ & Dummy & 0.36 & 0.00 & 1.00 & 0.00 & 0.48 & 0.58 & 1.34 & 6,401 & 0.00 & 78,736 \\
\hline$L A W \_S C$ & Dummy & 0.09 & 0.00 & 1.00 & 0.00 & 0.28 & 2.95 & 9.67 & 123,328 & 0.00 & 78,736 \\
\hline$L A W \_U K$ & Dummy & 0.31 & 0.00 & 1.00 & 0.00 & 0.46 & 0.82 & 1.68 & 6,946 & 0.00 & 78,736 \\
\hline $\begin{array}{l}\text { SOCIAL PROGRESS } \\
\text { INDEX }\end{array}$ & Abs. & 73.12 & 68.40 & 89.05 & 0.00 & 12.87 & -0.73 & 5.73 & 14,856 & 0.00 & 78,736 \\
\hline $\begin{array}{l}\text { BASIC_ } \\
\text { HUMAN_NEEDS }\end{array}$ & Abs. & 83.44 & 80.28 & 96.43 & 0.00 & 11.64 & -1.90 & 13.09 & 180,873 & 0.00 & 78,736 \\
\hline WELBEING & Abs. & 76.39 & 74.47 & 92.27 & 0.00 & 11.70 & -0.31 & 3.17 & 652 & 0.00 & 78,736 \\
\hline OPPORTUNITY & Abs. & 60.00 & 55.79 & 82.12 & 0.00 & 15.60 & 0.06 & 1.52 & 3,447 & 0.00 & 78,736 \\
\hline $\begin{array}{l}\text { ADVANCED_- } \\
\text { EDUCATION }\end{array}$ & Abs. & 42.55 & 35.11 & 68.46 & 0.00 & 14.70 & 0.34 & 1.95 & 2,459 & 0.00 & 78,736 \\
\hline $\begin{array}{l}\text { FOREIGN_ } \\
\text { HOLDINGS }\end{array}$ & $\%$ & 4.25 & 0.00 & 100.00 & 0.00 & 12.81 & 3.90 & 19.17 & 501,559 & 0.00 & 78,736 \\
\hline BETA_VALUES & Abs. & 0.93 & 0.96 & 2.42 & 0.00 & 0.38 & -0.02 & 2.80 & 61 & 0.00 & 78,736 \\
\hline $\begin{array}{l}\text { DIV_PER } \\
\text { NET_SALES }\end{array}$ & $\%$ & 4.16 & 1.60 & 266.68 & 0.00 & 9.17 & 8.80 & 146.91 & $32,717,658$ & 0.00 & 78,736 \\
\hline $\begin{array}{l}\text { DIVIDEND_ } \\
\text { PAYER }\end{array}$ & Dummy & 0.76 & 1.00 & 1.00 & 0.00 & 0.43 & -1.20 & 2.44 & 9,453 & 0.00 & 78,736 \\
\hline$D P R$ & $\%$ & 33.03 & 30.00 & 100.00 & 0.00 & 28.02 & 0.52 & 2.33 & 2,388 & 0.00 & 78,736 \\
\hline LEVERAGE & $\%$ & 0.81 & 0.51 & 41.83 & 0.00 & 1.20 & 7.73 & 136.22 & $27,996,487$ & 0.00 & 78,736 \\
\hline LN_TOTALASSETS & Abs. & 15.85 & 15.31 & 25.44 & 6.57 & 2.78 & 0.63 & 3.10 & 2,456 & 0.00 & 78,736 \\
\hline ROE & $\%$ & 15.00 & 12.61 & 61.05 & 0.00 & 11.24 & 1.22 & 4.57 & 13,075 & 0.00 & 78,736 \\
\hline
\end{tabular}

Source: Own calculation using Eviews 10.0 


\section{Appendix 2: Correlation matrix between variables}

The maximum level of correlation between variables introduced in the same model is maximum $30 \%$.

\begin{tabular}{|c|c|c|c|c|c|c|c|c|c|c|c|c|c|c|c|c|c|}
\hline Correlation & 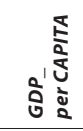 & $\begin{array}{l}\sqrt[3]{5} \\
3 \\
3 \\
3\end{array}$ & 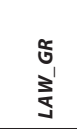 & $\begin{array}{l}u \\
u \\
3 \\
s\end{array}$ & 产產出 & 芯怘 & 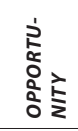 & 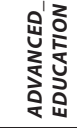 & 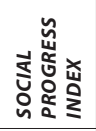 & $\begin{array}{l}5 \\
3 \\
3 \\
3 \\
3\end{array}$ & 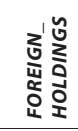 & 㤐岕 & 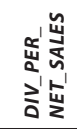 & 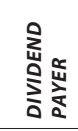 & $\frac{a}{a}$ & 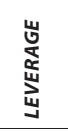 & 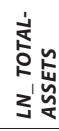 \\
\hline GDP_per CAPITA & 1.000 & - & - & - & - & - & - & - & - & - & - & - & - & - & - & - & - \\
\hline$L A W_{-} F R$ & -0.123 & 1.000 & - & - & - & - & - & - & - & - & - & - & - & - & - & - & - \\
\hline$L A W_{-} G R$ & -0.307 & -0.405 & 1.000 & - & - & - & - & - & - & - & - & - & - & - & - & - & - \\
\hline$L A W \_S C$ & 0.557 & -0.190 & -0.247 & 1.000 & - & - & - & - & - & - & - & - & - & - & - & - & - \\
\hline BASIC_HUMAN_NEEDS & 0.676 & -0.125 & -0.023 & 0.347 & 1.000 & - & - & - & - & - & - & - & - & - & - & - & - \\
\hline WELBEING & 0.863 & -0.112 & -0.210 & 0.391 & 0.858 & 1.000 & - & - & - & - & - & - & - & - & - & - & - \\
\hline OPPORTUNITY & 0.863 & -0.077 & -0.356 & 0.441 & 0.754 & 0.901 & 1.000 & - & - & - & - & - & - & - & - & - & - \\
\hline ADVANCED_EDUCATION & 0.822 & -0.196 & -0.194 & 0.255 & 0.764 & 0.887 & 0.890 & 1.000 & - & - & - & - & - & - & - & - & - \\
\hline $\begin{array}{l}\text { SOCIAL PROGRESS } \\
\text { INDEX }\end{array}$ & 0.791 & -0.110 & -0.206 & 0.405 & 0.947 & 0.925 & 0.914 & 0.864 & 1.000 & - & - & - & - & - & - & - & - \\
\hline$L A W_{-} U K$ & 0.061 & -0.378 & -0.490 & -0.230 & -0.090 & 0.060 & 0.145 & 0.210 & 0.046 & 1.000 & - & - & - & - & - & - & - \\
\hline FOREIGN_HOLDINGS & 0.110 & 0.100 & -0.119 & 0.015 & 0.063 & 0.093 & 0.139 & 0.097 & 0.096 & 0.020 & 1.000 & - & - & - & - & - & - \\
\hline BETA_VALUES & -0.040 & -0.095 & 0.291 & -0.133 & 0.041 & -0.019 & -0.079 & 0.063 & -0.015 & -0.123 & -0.052 & 1.000 & - & - & - & - & - \\
\hline DIV_PER_NET_SALES & 0.048 & 0.034 & -0.167 & -0.036 & -0.005 & 0.038 & 0.069 & 0.063 & 0.031 & 0.164 & 0.016 & -0.123 & 1.000 & - & - & - & - \\
\hline DIVIDEND_PAYER & 0.048 & 0.041 & -0.132 & -0.080 & 0.024 & 0.094 & 0.106 & 0.107 & 0.080 & 0.151 & 0.006 & -0.084 & 0.287 & 1.000 & - & - & - \\
\hline$D P R$ & 0.070 & 0.029 & -0.196 & -0.040 & 0.062 & 0.111 & 0.112 & 0.106 & 0.097 & 0.200 & 0.023 & -0.201 & 0.418 & 0.711 & 1.000 & - & - \\
\hline LEVERAGE & 0.004 & 0.010 & 0.003 & 0.002 & 0.007 & 0.005 & -0.001 & 0.004 & 0.006 & -0.013 & 0.004 & 0.025 & -0.029 & -0.065 & -0.055 & 1.000 & - \\
\hline LN_TOTALASSETS & -0.146 & 0.287 & -0.025 & -0.199 & -0.165 & -0.120 & -0.072 & -0.111 & -0.099 & -0.107 & 0.033 & 0.114 & -0.021 & 0.238 & 0.041 & 0.056 & 1.000 \\
\hline
\end{tabular}

Source: Own calculation using Eviews 10.0 


\begin{tabular}{|c|c|c|c|c|c|c|c|c|c|}
\hline \multirow[b]{2}{*}{$\dot{0}$} & \multirow[b]{2}{*}{ 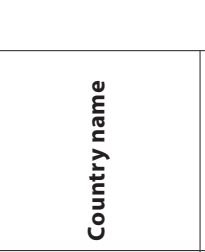 } & \multirow[b]{2}{*}{ 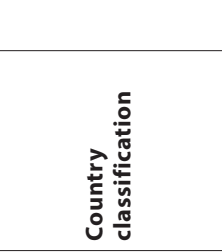 } & \multirow[b]{2}{*}{ 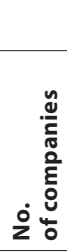 } & \multicolumn{6}{|c|}{2014 data } \\
\hline & & & & 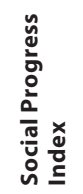 & 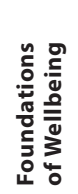 & 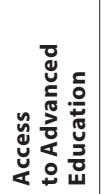 & 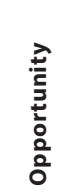 & 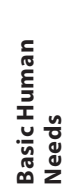 & 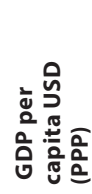 \\
\hline 1 & Denmark & developed country & 236 & 89.05 & 89.06 & 55.47 & 82.12 & 95.96 & 42,879 \\
\hline 2 & Netherlands & developed country & 50 & 88.91 & 91.04 & 55.84 & 79.59 & 96.08 & 46,309 \\
\hline 3 & Sweden & developed country & 48 & 88.86 & 89.35 & 58.17 & 81.22 & 96.02 & 43,719 \\
\hline 4 & Switzerland & developed country & 34 & 88.84 & 89.60 & 61.57 & 80.49 & 96.43 & 54,534 \\
\hline 5 & Norway & developed country & 311 & 88.76 & 91.64 & 51.43 & 79.41 & 95.22 & 62,571 \\
\hline 6 & Finland & developed country & 230 & 88.71 & 89.73 & 54.05 & 81.00 & 95.39 & 40,378 \\
\hline 7 & Germany & developed country & 54 & 88.24 & 89.37 & 60.53 & 80.14 & 95.21 & 43,221 \\
\hline 8 & United Kingdom & developed country & 176 & 87.90 & 90.75 & 67.93 & 78.84 & 94.10 & 36,654 \\
\hline 9 & Australia & developed country & 358 & 87.73 & 88.73 & 68.46 & 80.19 & 94.27 & 42,807 \\
\hline 10 & Ireland & developed country & 74 & 87.51 & 87.48 & 66.15 & 80.20 & 94.86 & 45,960 \\
\hline 11 & New Zealand & developed country & 90 & 87.40 & 88.62 & 61.51 & 78.93 & 94.64 & 32,311 \\
\hline 12 & France & developed country & 74 & 87.38 & 91.63 & 58.32 & 76.89 & 93.62 & 38,657 \\
\hline 13 & Canada & developed country & 438 & 87.21 & 88.03 & 67.15 & 80.83 & 92.77 & 41,523 \\
\hline 14 & Belgium & developed country & 36 & 87.05 & 87.54 & 56.67 & 79.13 & 94.47 & 41,077 \\
\hline 15 & Japan & developed country & 407 & 87.02 & 92.27 & 57.76 & 73.57 & 95.23 & 34,332 \\
\hline 16 & Spain & developed country & 52 & 86.27 & 89.33 & 56.55 & 75.34 & 94.14 & 32,467 \\
\hline 17 & Austria & developed country & 34 & 86.08 & 88.95 & 49.22 & 73.34 & 95.94 & 44,397 \\
\hline 18 & Luxembourg & developed country & 14 & 85.81 & 89.25 & 34.32 & 73.43 & 94.74 & 90,950 \\
\hline 19 & United States & developed country & 884 & 85.70 & 84.50 & 71.72 & 80.28 & 92.33 & 49,726 \\
\hline 20 & Italy & developed country & 60 & 84.48 & 88.58 & 58.88 & 73.67 & 91.19 & 35,896 \\
\hline 21 & Slovenia & developed country & 12 & 83.76 & 85.51 & 44.34 & 71.05 & 94.70 & 28,774 \\
\hline 22 & Portugal & developed country & 74 & 82.92 & 82.54 & 42.36 & 71.43 & 94.79 & 26,588 \\
\hline 23 & Czech Republic & developed country & 22 & 82.83 & 82.75 & 43.63 & 70.61 & 95.13 & 28,481 \\
\hline 24 & Estonia & developed country & 34 & 82.11 & 85.29 & 53.39 & 71.63 & 89.39 & 23,919 \\
\hline 25 & Israel & developed country & 167 & 81.90 & 87.47 & 61.23 & 66.99 & 91.24 & 30,585 \\
\hline
\end{tabular}




\begin{tabular}{|c|c|c|c|c|c|c|c|c|c|}
\hline \multirow[b]{2}{*}{$\dot{0}$} & \multirow[b]{2}{*}{ 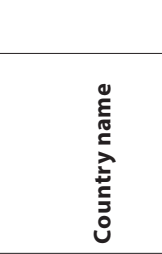 } & \multirow[b]{2}{*}{ 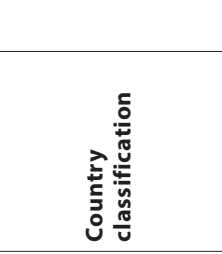 } & \multirow[b]{2}{*}{ 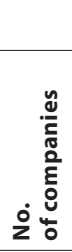 } & \multicolumn{6}{|c|}{2014 data } \\
\hline & & & & 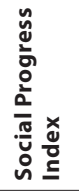 & 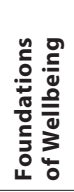 & 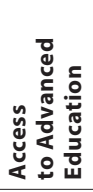 & $\begin{array}{l}\frac{2}{5} \\
\frac{2}{2} \\
\frac{1}{0} \\
\frac{0}{0} \\
0\end{array}$ & 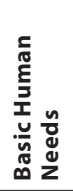 & 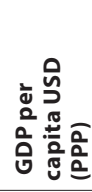 \\
\hline 26 & Greece & developed country & 106 & 81.70 & 85.7 & 54.35 & 68.09 & 91.32 & 26,850 \\
\hline 27 & Poland & emerging country & 597 & 80.74 & 80.86 & 45.05 & 69.26 & 92.10 & 22,571 \\
\hline 28 & Lithuania & developed country & 68 & 80.46 & 81.6 & 48.46 & 71.78 & 88.00 & 22,743 \\
\hline 29 & Hungary & emerging country & 20 & 79.52 & 78.97 & 42.66 & 68.31 & 91.30 & 22,785 \\
\hline 30 & Chile & emerging country & 182 & 79.49 & 81.38 & 41.70 & 67.71 & 89.36 & 20,187 \\
\hline 31 & Croatia & emerging country & 48 & 78.30 & 80.52 & 43.01 & 63.19 & 91.18 & 20,438 \\
\hline 32 & Latvia & developed country & 62 & 77.97 & 81.08 & 34.16 & 64.25 & 88.58 & 19,760 \\
\hline 33 & Argentina & emerging country & 18 & 74.26 & 76.27 & 40.39 & 64.13 & 82.38 & 21,027 \\
\hline 34 & Bulgaria & emerging country & 16 & 73.63 & 72.61 & 35.63 & 61.35 & 86.92 & 16,559 \\
\hline 35 & Romania & emerging country & 124 & 73.43 & 75.31 & 37.05 & 60.37 & 84.61 & 17,326 \\
\hline 36 & Brazil & emerging country & 120 & 73.34 & 76.45 & 35.11 & 63.91 & 79.66 & 15,062 \\
\hline 37 & Mauritius & emerging country & 66 & 73.27 & 74.31 & 16.38 & 55.76 & 89.73 & 16,179 \\
\hline 38 & $\begin{array}{l}\text { United Arab } \\
\text { Emirates }\end{array}$ & emerging country & 50 & 72.33 & 77.39 & 36.98 & 53.04 & 86.55 & 58,917 \\
\hline 39 & Serbia & emerging country & 202 & 71.6 & 71.78 & 41.48 & 55.72 & 87.3 & 12,628 \\
\hline 40 & Tunisia & emerging country & 80 & 71.17 & 74.7 & 18.28 & 55.1 & 83.72 & $\# N / A$ \\
\hline 41 & Malaysia & emerging country & 46 & 70.87 & 74.19 & 38.6 & 50.69 & 87.73 & 21,498 \\
\hline 42 & Russia & emerging country & 88 & 68.64 & 71.81 & 57.93 & 53.82 & 80.28 & 24,068 \\
\hline 43 & Mexico & emerging country & 64 & 68.6 & 71.29 & 40.2 & 55.79 & 78.72 & 15,754 \\
\hline 44 & Peru & emerging country & 24 & 68.58 & 76.24 & 31.96 & 53.62 & 75.88 & 10,293 \\
\hline 45 & Ukraine & emerging country & 82 & 68.48 & 66.75 & 45.66 & 56.33 & 82.37 & 8,328 \\
\hline 46 & Thailand & emerging country & 888 & 68.4 & 74.47 & 33.16 & 50.81 & 79.91 & 13,506 \\
\hline 47 & Turkey & emerging country & 162 & 67.84 & 72.97 & 30.94 & 45.55 & 85.01 & 17,715 \\
\hline 48 & Oman & emerging country & 38 & 67.37 & 74.69 & 21.07 & 42.29 & 85.12 & 45,406 \\
\hline 49 & Macedonia & emerging country & 52 & 67.22 & 67.37 & 26.29 & 47.66 & 86.62 & 12,064 \\
\hline
\end{tabular}




\begin{tabular}{|c|c|c|c|c|c|c|c|c|c|}
\hline \multirow[b]{2}{*}{$\dot{0}$} & \multirow[b]{2}{*}{ 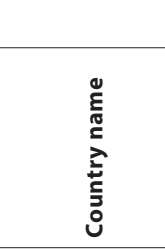 } & \multirow[b]{2}{*}{ 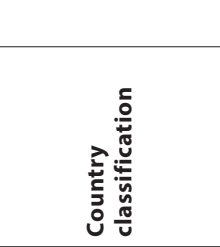 } & \multirow[b]{2}{*}{ 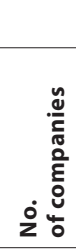 } & \multicolumn{6}{|c|}{2014 data } \\
\hline & & & & 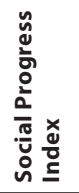 & 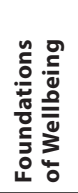 & 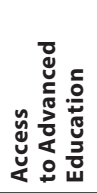 & 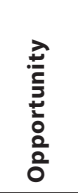 & 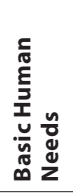 & 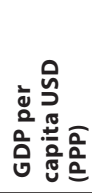 \\
\hline 50 & Kazakhstan & emerging country & 61 & 65.32 & 67.01 & 43.14 & 48.07 & 80.87 & 20,626 \\
\hline 51 & Sri Lanka & emerging country & 366 & 64.78 & 72.31 & 28.24 & 46.05 & 75.97 & 8,241 \\
\hline 52 & South Africa & emerging country & 278 & 64.24 & 63.44 & 33.18 & 63.21 & 66.07 & 12,291 \\
\hline 53 & Morocco & emerging country & 140 & 63.81 & 68.81 & 10.83 & 41.74 & 80.87 & 6,929 \\
\hline 54 & Saudi Arabia & emerging country & 180 & 63.6 & 70.73 & 35.41 & 34.72 & 85.34 & 48,163 \\
\hline 55 & Philippines & emerging country & 52 & 61.78 & 65.39 & 32.49 & 52.64 & 67.32 & 5,735 \\
\hline 56 & China & emerging country & 1,542 & 61.64 & 65.68 & 31.49 & 41.83 & 77.41 & 10,181 \\
\hline 57 & Indonesia & emerging country & 599 & 60.79 & 62.72 & 26.05 & 49.63 & 70.03 & 8,974 \\
\hline 58 & Egypt & emerging country & 68 & 58.88 & 61.25 & 36.42 & 39.53 & 75.88 & 11,036 \\
\hline 59 & Ghana & emerging country & 52 & 56.6 & 59.62 & 11.13 & 50.38 & 59.81 & 3,519 \\
\hline 60 & India & emerging country & 164 & 53.97 & 55.87 & 24.71 & 48.49 & 57.55 & 4,749 \\
\hline 61 & Kenya & emerging country & 22 & 52.16 & 62.21 & 16.19 & 40.61 & 53.67 & 2,750 \\
\hline 62 & Bangladesh & emerging country & 68 & 49.37 & 50.25 & 11.8 & 37.86 & 60.02 & 2,785 \\
\hline 63 & Pakistan & emerging country & 144 & 45.69 & 44.78 & 15.67 & 35.54 & 56.74 & 4,350 \\
\hline 64 & Cote d'Ivoire & emerging country & 58 & 44.18 & 44.94 & 7.58 & 38.36 & 49.24 & 2,453 \\
\hline 65 & Zimbabwe & emerging country & 112 & 42.43 & 53.67 & 14.6 & 34.04 & 39.57 & 1,717 \\
\hline 66 & Bahrain & emerging country & 50 & N/A & 78.78 & 33.82 & 41.27 & N/A & 43,362 \\
\hline 67 & Kuwait & emerging country & 36 & $\mathrm{~N} / \mathrm{A}$ & 78.67 & 38.17 & 52.84 & $\mathrm{~N} / \mathrm{A}$ & 67,131 \\
\hline 68 & Malta & developed country & 30 & $\mathrm{~N} / \mathrm{A}$ & 83.62 & 23.11 & $\mathrm{~N} / \mathrm{A}$ & $N / A$ & 29,726 \\
\hline 69 & Venezuela & emerging country & 14 & N/A & $\mathrm{N} / \mathrm{A}$ & 35.11 & 63.91 & 69.67 & 17,210 \\
\hline 70 & Zambia & emerging country & 40 & N/A & $\mathrm{N} / \mathrm{A}$ & 11.32 & 42.49 & 44.53 & 3,342 \\
\hline
\end{tabular}

Source: Own table using data from the data sources mentioned in chapter III 


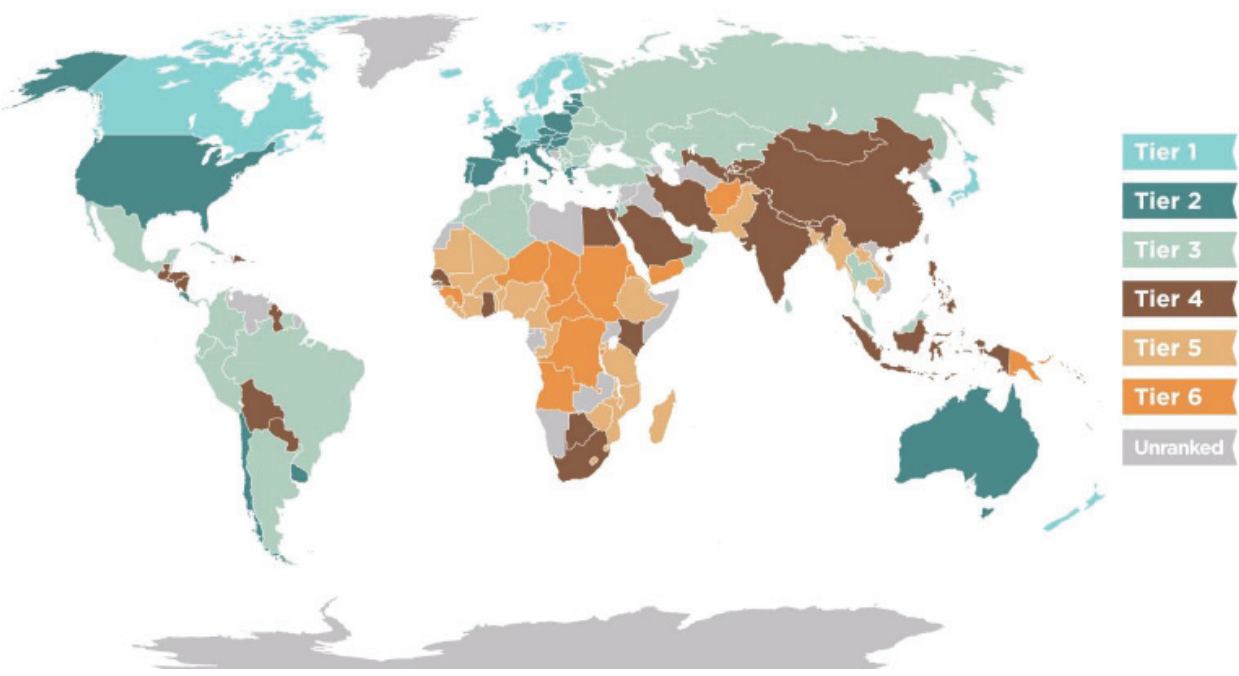

Source: https://www.socialprogress.org/

\section{Appendix 5: Visualisation of the relationship between SPI and DPR in 2014}

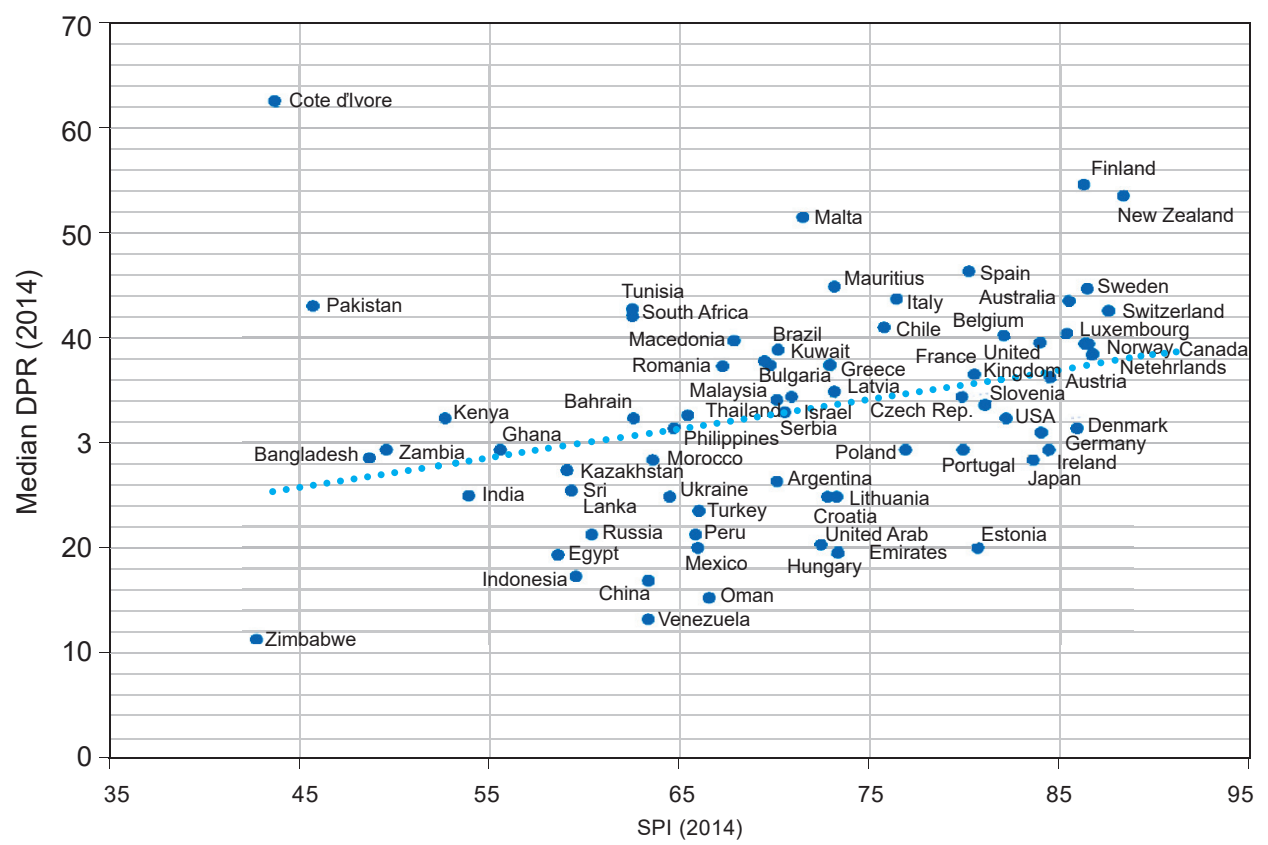

Source: Own graph using SPI data from Social Progress Imperative and Median DPR based on companies' financial statements exported from Thomson Research Worldscope Database 
Appendix 6: Explicative variable definitions and related studies

\begin{tabular}{|c|c|}
\hline Variable & Definition \\
\hline $\begin{array}{l}\text { RETURN ON EQUITY } \\
\text { (ROE) }\end{array}$ & $\frac{\text { Net Profit }_{t}}{\text { Equity }_{t}}$ \\
\hline $\begin{array}{l}\text { COMPANY SIZE } \\
\text { (LN_TOTAL ASSETS) }\end{array}$ & Ln (Total Assets $\left.{ }_{\mathrm{t}}\right)$ \\
\hline $\begin{array}{l}\text { VOLATILITY } \\
\text { (BETA VALUE) }\end{array}$ & 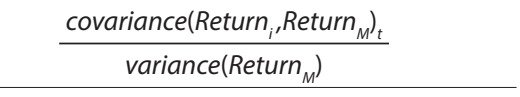 \\
\hline $\begin{array}{l}\text { LEVERAGE } \\
(\operatorname{LEV}(-1))\end{array}$ & $\frac{\text { Total liabilities }_{t-1}}{\text { Equity }_{t}}$ \\
\hline $\begin{array}{l}\text { OWNERSHIP } \\
\text { (FOREIGN HOLDINGS) }\end{array}$ & $\begin{array}{l}\text { The percentage of shares held by foreign } \\
\text { investors in the company }\end{array}$ \\
\hline $\begin{array}{l}\text { LEGAL ORIGINS } \\
\text { (FRENCH_CIVIL LAW } \\
\text { GERMAN_CIVILLAW } \\
\text { SCANDINAVIAN_CIVIL } \\
\text { LAW,COMMON LAW) }\end{array}$ & $\begin{array}{l}\text { Dummy variable for legal origin - The origin } \\
\text { of the legal system as it was provided } \\
\text { by Andrei Shleifer }\end{array}$ \\
\hline
\end{tabular}

Note: " $\mathrm{i}$ " is the share of the company, $\mathrm{M}$ is market return, $\mathrm{t}$ is the year and (t-1) is the previous year. Source: Yaseen, H. (forthcoming). Classical Factors Still Influence Significantly the Dividend Policy. An International Evidence. Paper under final review by the Journal of Economics.

\section{References}

Ackhil, G., Ferguson, J. (1992). Beyond "Culture": Space, Identity, and the Politics of Difference. Cultural Anthropology, 7(1), 6-23, https://doi.org/10.1525/can.1992.7.1.02a00020

Aivazian, V., Booth, L., Cleary, L. S. (2003). Do Emerging Market Firms Follow Different Dividend Policies From U.S. Firms? The Journal of Financial Research, 26(3), 371-387, https://doi.org/10.1111/1475-6803.00064

Bae, S., Chang, K., Kang, E. (2012). Culture, Corporate Governance and Dividend Policy: International Evidence. Journal of Financial Research, 35(2), 289-316, https://doi.org/10.1111/j.1475-6803.2012.01318.x

Baker, H. K., Singleton, J. C., Veit, E. T. (2011). Survey Research in Corporate Finance - Bridging the Gap between Theory and Practice. New York, NY: Oxford University Press, https://doi.org/10.1093/acprof:oso/9780195340372.001.0001

Benartzi, S., Michaely, R., Thaler, R. (1997). Do Changes in Dividends Signal the Future or the Past? Journal of Finance, 52(3), 1007-1034, https://doi. org/10.1111/j.1540-6261.1997.tb02723.x

Bhattacharya, S. (1979). Imperfect Information, Dividend Policy, and the Bird in Hand Fallacy. The Bell Journal of Economics, 10(1), 259-270, https://doi.org/10.2307/3003330 
Brav, A., Graham, J. R., Harvey, C. R., et al. (2005). Payout Policy in the 21st Century. Journal of Financial Economics, 77(3), 483-527, https://doi.org/10.1016/j.jfineco.2004.07.004

Brockman, P. Unlu, E. (2009). Dividend Policy, Creditor Rights, and the Agency Costs of Debt. Journal of Financial Economics, 92(2), 276-299, https://doi.org/10.1016/j. jfineco.2008.03.007

Chen, J., Woon, S. L., Marc, G. (2017). The Impact of Board Gender Composition on Dividend Payout. Journal of Corporate Finance, 43, 86-105, https://doi.org/10.1016/j. jcorpfin.2017.01.001

DeAngelo, H., DeAngelo, L., Skinner, D. J. (1996). Reversal of Fortune: Dividend Signaling and the Disappearance of Sustained Earnings Growth. Journal of Financial Economics, 40(3), 341-371, https://doi.org/10.1016/0304-405X(95)00850-E

DeAngelo, H., DeAngelo, L., Skinner, D. J. (2008). Corporate Payout Policy. Foundations and Trends in Finance, 3(2/3), 95-287, https://doi.org/10.1108/MF-03-2014-0077

Denis, D., Osobov, I. (2008). Why do Firms Pay Dividend? International Evidence on the Determinants of Dividend Policy. Journal of Financial Economics, 89, https://doi.org/10.1016/j.jfineco.2007.06.006

Dipietro, W. R., Anoruo, E. (2006). GDP Per Capita and its Challengers as Measures of Happiness. International Journal of Social Economics, 33(10), 698-709, https://doi. org/10.1108/03068290610689732

Dragotă, V. (2003). Politica de dividend. O abordare in contextul mediului economic din Romania. Ed. All Beck, ISBN 973-655-383-3.

Dragotă, M., Dragotă, V., Ţâţu, L., et al. (2009). Income Taxation Regulation and Companies' Behaviour: Is the Romanian Companies' Dividend Policy Influenced by the Changes in Income Taxation? Romanian Journal of Economic Forecasting, 6(1), 76-93.

Dragotă, V., Pele, D. T., Yaseen, H. (2019). Dividend Payout Ratio follows a Tweedie Distribution: international evidence. Economics: The Open-Access, Open-Assessment E-Journal, 13 (2019-45): 1-34. http://www.economics-ejournal.org/economics/journalarticles/2019-45

Dragota, V., Yaseen, H. (forthcoming). Egalitarianism and Hierarchy in Dividend Policy. Paper presented within FIBA conference, 28-29 ${ }^{\text {th }}$ of March 2019, at The Bucharest University of Economic Studies.

Easterbrook, F. (1984). Two Agency-cost Explanations of Dividends. American Economic Review, 74, 650-659. Available at: https://www.jstor.org/stable/1805130

England, R. W. (1998). Analysis: Measurement of Social Well-being: Alternatives to Gross Domestic Product. Ecological Economics, 25(1), 89-103, https://doi.org/10.1016/ s0921-8009(97)00098-0

Fama, E. F., French, K. R. (2001). Disappearing Dividends: Changing Firm Characteristics or Lower Propensity to Pay? Journal of Financial Economics, 60, 3-40.

Fidrmuc, J., Jacob, M. (2010). Culture, Agency Cost and Dividends. Journal of Comparative Economics, 38(3), 321-339, https://doi.org/10.1016/j.jce.2010.04.002 
Fleurbaey, M., Blanchet, D. (2013). Beyond GDP: Measuring Welfare and Assessing Sustainability. Oxford University Press. ISBN 9780199767199.Social Indicators Research, 87(1), 1-25, https://doi.org/10.1007/s11205-007-9158-7

Guiso, L., Sapienza, P., Zingales, L. (2006). Does Culture Affect Economic Outcomes? The Journal of Economic Perspectives, 20(2), 23-48, https://doi.org/10.1257/jep.20.2.23

Hahn, A., R., Inborn, M. (2009). Anthropology and Public Health: Bridging Differences in Culture and Society. Published to Oxford Scholarship Online, https://doi.org/10.1093/acprof: oso/9780195374643.001.0001

Jensen, M. C. (1986). Agency Costs of Free Cash Flow, Corporate Finance, and Takeovers. American Economic Review, 76(2), 323-329. Available at: https://sfinm.files.wordpress. com/2013/10/agency-costs-of-fcf-jensen.pdf

La Porta, R., Lopez-de-Silanes, F., Shleifer, A., et al. (2000). Agency Problems and Dividend Policies around the World. Journal of Finance, 55(1), 1-33, https://doi. org/10.1111/0022-1082.00199

La Porta, R., Lopez-de-Silanes, F., Shleifer, A. (2008). The Economic Consequences of Legal Origins. Journal of Economic Literature, 46(2), 285-332. Available at: http://scholar. harvard.edu/shleifer/publications/economic-consequences-legal-origins

Lintner, J. (1962). Dividends, Earnings, Leverage, Stock Prices and the Supply of Capital to Corporations. The Review of Economics and Statistics, 44(3), 243-269, https://doi.org/10.2307/1926397

Miller, M. H., Modigliani, F. (1961). Dividend Policy, Grow and the Valuation of Share. The Journal of Business, 34(4), 411-433, https://doi.org/10.1086/294442

Miller, M. H., Rock, K. (1985). Dividend Policy under Asymmetric Information. Journal of Finance, 40(4), 1031-1052, https://doi.org/10.1111/j.1540-6261.1985.tb02362.x

Shao, Y., Kwok, C., Guedhami, O. (2010). National Culture and Dividend Policy. Journal of International Business Studies, 41(8), 1391-1414, https://doi.org/10.1057/jibs.2009.74

Yaseen, H. (2018). Dividend Policy and Socio-Cultural Factors: Some Preliminary Findings. The Review of Finance and Banking, 10 (2), 077-094

Yaseen, H. (2019). Dividend Policy Explained by Country's Standards of Living: An International Evidence, in Procházka, D., ed., Global Versus Local Perspectives on Finance and Accounting. Cham: ACFA2018, Springer Proceedings in Business and Economics, 125-134, https://doi.org/10.1007/978-3-030-11851-8_12

Yaseen, H., Dragotă, V. (2019). Harmony, Hierarchy and Dividend Policy around the World, in Procházka, D., ed., Global Versus Local Perspectives on Finance and Accounting. Cham: ACFA2018 2, Springer Proceedings in Business and Economics. Springer, pp. 115-124, https://doi.org/10.1007/978-3-030-11851-8_11

https://www.socialprogress.org/

https://data.worldbank.org/indicator/SI.POV.GINI/ 